\title{
Available Fluoride in Toothpastes Used by Brazilian Children
}

\author{
Jaime Aparecido CURY ${ }^{1}$ \\ Maria José Lages de OLIVEIRA² \\ Carolina Castro MARTINS ${ }^{3}$ \\ Livia Maria Andaló TENUTA ${ }^{1}$ \\ Saul Martins PAIVA ${ }^{3}$ \\ ${ }^{1}$ Piracicaba Dental School, University of Campinas, Piracicaba SP, Brazil \\ ${ }^{2}$ Dental School, State University of Montes Claros, Montes Claros, MG, Brazil \\ ${ }^{3}$ Federal University of Minas Gerais, Belo Horizonte, MG, Brazil
}

\begin{abstract}
Toothpastes should have a minimum concentration of $1000 \mathrm{ppm}$ of fluoride (F) to control caries and also the active $\mathrm{F}$ agent must be chemically free (soluble) in the formulation. Thus, the aim of this study was to evaluate the concentration of soluble $\mathrm{F}$ in dentifrices used by 206 Brazilian children. The concentrations of total fluoride (TF), total soluble fluoride (TSF) and fluoride ion were determined. From these analyses, the concentrations of $\mathrm{F}$ as sodium monofluorophosphate (MFP) and \% of insoluble F were calculated. F was analyzed with an ion specific electrode in duplicates. The majority of dentifrices used $(96 \%)$ contained $\mathrm{F}$ and in $84 \%$ of them, TF concentration was according to that declared by the manufacturers. In the F-toothpastes, $78 \%$ showed TSF concentration $\geq 1000 \mathrm{ppm}$, varying from 422.3 to $1432.3 \mathrm{ppm} \mathrm{F}$ (mean $\pm \mathrm{SD}$ of $1017.6 \pm 239.4$ ). These findings suggest that most dentifrices used by Brazilian children present available fluoride concentration for caries control.
\end{abstract}

Key Words: dentifrice, toothpaste, fluoride, dental caries.

\section{INTRODUCTION}

The evidence about the effect of fluoride (F) toothpaste on caries control is strongly supported by the literature (1). Also, F-toothpaste is considered responsible for the caries decline reported either in developed countries after the 1980's (2) or developing ones after the 1990's (3). Furthermore, it is considered the most rational way of fluoride use because it combines the regular disruption of dental plaque, the necessary factor responsible for caries, with the therapeutic interference of $\mathrm{F}$ with the caries process.

However, F must be chemically free (soluble) in the toothpaste formulation (4), assuring $\mathrm{F}$ bioavailability in the oral cavity during toothbrushing (5). This bioavailability depends on the chemical compatibility between the type of $\mathrm{F}$ added to the formulation and the abrasive used (6). In Brazil (3) and in most developing countries (7), the majority of the toothpastes contain calcium carbonate as abrasive, which may inactivate part of $\mathrm{F}$ present in the commercial products, even if they are formulated with sodium monofluorophosphate (MFP) (8).

Moreover, the requirement that toothpastes should have soluble F in their formulations (4) is of increased relevance since a recent systematic review of the literature evidenced that only toothpastes with 1000 ppm F or more would have anticaries effect (9). However, the legislation of some countries or common markets as EU (10) and Mercosur (11) does not require that manufactures demonstrate how much of $\mathrm{F}$ is soluble in the product. They only establish that "when mixed with other fluoride compounds, the permitted total $\mathrm{F}$ concentration must not exceed $0.15 \%$ " (1500 ppm F).

The aim of this study was to evaluate the concentration of soluble $\mathrm{F}$ in toothpastes used by Brazilian children, considering its anticaries potential. It was also evaluated if the maximum concentration 
established by Brazilian guidelines was being followed.

\section{MATERIAL AND METHODS}

This study was approved by the Human Ethics Committee of Federal University of Minas Gerais (COEP - UFMG - Protocol number: 278/07). All parents/ guardians of children involved in the study received information regarding the objectives of the study and signed informed consent forms.

Toothpastes that were being used by 206 Brazilian children aged 9 to 48 months (mean $=41.0 \pm 6.6$ ) living in Montes Claros, a medium-sized city of southeastern Brazil, were collected for analysis. Four public and four private kindergartens were selected to take part in the study. The institutions were selected through randomized drafts from a list containing all kindergartens of the city.

Parents were requested to bring the toothpaste that the children usually used at home in a meeting of parents at the kindergarten. In exchange, the parents received a kit containing a child tooth brush and a fluoridated toothpaste, and verbal orientations on oral health. For the analysis, the toothpastes were randomly coded with letters allowing blind analysis of $\mathrm{F}$ concentration. When more than 3 children were using toothpastes of the same brand, 3 tubes were randomly selected for analysis. When 3 or fewer children were using a brand, all tubes were analyzed. All toothpastes were analyzed before the expiration date declared by the manufacturer. The 206 toothpastes comprised 30 commercial brands (Table 1), which are ranked with a single-letter (26 brands) or a two-letter code (the other 4 brands), according to the percentage of consumption by the children.

As to the determination of $F$ concentration, 3 forms of $\mathrm{F}$ available in the toothpastes were determined: $\mathrm{F}$ ion (FI), total soluble F (TSF) (the sum of FI plus fluoride as MFP) and total F (TF) (the sum of total soluble fluoride (TSF) plus insoluble F (IF) that is the F bound to the abrasive). From these analyses, the concentrations of $F$ as MFP and the percentage of IF were calculated.

Analyses were carried out in duplicates according to a protocol modified from Pearce (12), which has been used since 1980 at the Laboratory of Oral Biochemistry at Piracicaba Dental School, as described: 90 to $110 \mathrm{mg}$ of toothpaste were weighed $( \pm 0.01 \mathrm{mg})$, homogenized in $10.0 \mathrm{~mL}$ of deionized water and duplicates of $0.25 \mathrm{~mL}$ of the suspension were transferred to test tubes for TF analysis. The remaining of the suspension was centrifuged $(3,000 \mathrm{~g}, 10 \mathrm{~min}$, r.t.) to remove IF bound to the abrasive.
Duplicates of $0.25 \mathrm{~mL}$ of the supernatant were transferred to assay tubes to determine TSF and FI concentrations. For the TF and TSF tubes, $0.25 \mathrm{~mL}$ of $2.0 \mathrm{M} \mathrm{HCl}$ was added, and after $1 \mathrm{~h}$ at $45^{\circ} \mathrm{C}$, the samples were neutralized with $0.5 \mathrm{~mL} 1.0 \mathrm{M} \mathrm{NaOH} 1.0 \mathrm{M}$ and buffered with 1.0 mL of TISAB II (1.0 M acetate buffer, $\mathrm{pH}$ 5.0, containing $1.0 \mathrm{M} \mathrm{NaCl}$ and $0.4 \%$ CDTA). To the FI tubes, $0.50 \mathrm{~mL}$ of $1.0 \mathrm{M} \mathrm{NaOH}$ was added and buffered with $1.0 \mathrm{~mL}$ of TISAB II and $0.25 \mathrm{~mL}$ of $2.0 \mathrm{M} \mathrm{HCl}$. The analyses was carried out using a fluoride electrode (Orion model 9609, Orion Research, Cambridge, MA, USA) coupled to an ion analyzer (Orion EA-740), previously calibrated with $\mathrm{F}$ standards containing 0.06 to $8.0 \mathrm{ppm} \mathrm{F}$, prepared with the same reagents as the samples.

A linear regression between $\mathrm{F}$ concentration in standards and $\mathrm{mV}$ was constructed using the Microsoft Excel software and used to calculate the $\mathrm{F}$ concentration in each toothpaste, in ppm F. The variation coefficients of repeated analyses (duplicate) were lower than $2 \%$. The mean and standard deviation for each brand was calculated using Statistical Package for Social Sciences (SPSS for Windows, version 18.0, SPSS Inc., Chicago, IL, USA). The analysis was made in triplicate when less than 3 tubes of toothpaste were available.

\section{RESULTS}

Most children (95.6\%) were using toothpastes containing fluoride and among these, only 2 children were using toothpaste with low $\mathrm{F}$ concentration (Table 1). Among the F-toothpastes consumed, $57.7 \%$ contained $\mathrm{F}$ as MFP and $42.3 \%$ as NaF. The most consumed toothpaste was the brand A $(33.5 \%)$, which is formulated with 1100 ppm F (NaF, silica-based) and marketed directly to children.

Figure 1 shows that in most (84.4\%) toothpastes, total $\mathrm{F}$ (TF) concentration found in the analysis coincided with that declared in the label of the products. Disagreement ( $\geq$ or $\leq 5 \%$ ) between the concentration declared and that found was observed for the toothpastes G, K, P, Q and V. Also, all of these, except for K, had TF higher than the maximum allowed by the Brazilian legislation. TF found in the F-toothpastes varied from 521.6 to $1787.1 \mathrm{ppm} \mathrm{F}$ (mean \pm SD of $1242.8 \pm 280.9$ ).

Figure 2 illustrates the relationship between TF and TSF concentrations found in the F-toothpastes; in 48\% of them the TSF was lower than the TF, indicating that part of $\mathrm{F}$ was insoluble. TSF concentration varied from 422.3 to $1432.3 \mathrm{ppm} F($ mean $\pm \mathrm{SD}$ of $1017.0 \pm 239.4)$. 
Forty-four percent of the F-toothpastes presented only FI as the active agent and $56 \%$ had both FI and MFP; none of them contained only MFP as the active agent (data not shown). IF was found in toothpastes $\mathrm{B}, \mathrm{C}, \mathrm{D}, \mathrm{G}, \mathrm{H}$, I, K, P, Q, R, U, V and Y (data not shown). Percentage of IF varied from $14.9 \%$ to $53.4 \%$ (mean \pm SD of 34.9

Table 1. Toothpastes used by the children and information about the formulation.

\begin{tabular}{|c|c|c|c|c|c|}
\hline $\begin{array}{l}\text { Commercial } \\
\text { Brand }\end{array}$ & Code & $\begin{array}{l}\text { No. Children } \\
\text { using }(\%)\end{array}$ & $\begin{array}{c}\text { Fluoridated } \\
\text { agent }\end{array}$ & $\begin{array}{c}\text { *Fluoride } \\
\text { expected (ppm) }\end{array}$ & $\begin{array}{c}\text { Abrasive } \\
\text { agent }\end{array}$ \\
\hline Tandy & A & $69(33.5)$ & $\mathrm{NaF}$ & 1100 & $\mathrm{SiO}_{2}$ \\
\hline Sorriso Branco & $\mathrm{B}$ & $24(11.7)$ & MFP & 1450 & $\mathrm{CaCO}_{3}$ \\
\hline Colgate MPA & $\mathrm{C}$ & $21(10.2)$ & MFP & 1450 & $\mathrm{CaCO}_{3}$ \\
\hline Colgate Tripla Ação & $\mathrm{D}$ & $16(7.8)$ & MFP & 1450 & $\mathrm{CaCO}_{3}$ \\
\hline Colgate Jr & $\mathrm{E}$ & $11(5.3)$ & $\mathrm{NaF}$ & 1100 & $\mathrm{SiO}_{2}$ \\
\hline Seninha & $\mathrm{F}$ & $8(3.9)$ & MFP & 1188 & $\mathrm{SiO}_{2}$ \\
\hline Onda Fresh & $\mathrm{G}$ & $6(2.9)$ & MFP & 1500 & $\mathrm{CaCO}_{3}$ \\
\hline Close up Triple & $\mathrm{H}$ & $5(2.4)$ & MFP & 1500 & $\mathrm{CaCO}_{3}$ \\
\hline Contente Kids & I & $5(2.4)$ & MFP & 1000 & $\mathrm{CaCO}_{3}$ \\
\hline Colgate Total 12 & $\mathrm{~J}$ & $4(1.8)$ & $\mathrm{NaF}$ & 1450 & $\mathrm{SiO}_{2}$ \\
\hline Dentil Kids & $\mathrm{K}$ & $4(1.8)$ & MFP & 800 & n.a. \\
\hline Sanifill Kids & $\mathrm{L}$ & $4(1.8)$ & No $F$ & 0.0 & $\mathrm{SiO}_{2}$ \\
\hline Action Kids & M & $3(1.5)$ & $\mathrm{NaF}$ & 1100 & $\mathrm{SiO}_{2}$ \\
\hline Sorriso Fresh & $\mathrm{N}$ & $3(1.5)$ & $\mathrm{NaF}$ & 1100 & $\mathrm{SiO}_{2}$ \\
\hline Weleda & $\mathrm{O}$ & $3(1.5)$ & No F & 0.0 & $\mathrm{SiO}_{2}$ \\
\hline Contente Plus & $\mathrm{P}$ & $2(1.0)$ & MFP & 1500 & $\mathrm{CaCO}_{3}$ \\
\hline Ice Fresh & Q & $2(1.0)$ & MFP & 1500 & $\mathrm{CaCO}_{3}$ \\
\hline Sorriso Herbal & $\mathrm{R}$ & $2(1.0)$ & MFP & 1450 & $\mathrm{CaCO}_{3}$ \\
\hline Crest & $\mathrm{S}$ & $2(1.0)$ & $\mathrm{NaF}$ & 1100 & $\mathrm{SiO}_{2}$ \\
\hline Colgate Baby & $\mathrm{T}$ & $2(1.0)$ & $\mathrm{NaF}$ & 500 & $\mathrm{SiO}_{2}$ \\
\hline Colgate Herbal & $\mathrm{U}$ & $1(0.5)$ & MFP & 1450 & $\mathrm{CaCO}_{3}$ \\
\hline Condor $100 \%$ Branco & $\mathrm{V}$ & $1(0.5)$ & MFP & 1450 & $\mathrm{CaCO}_{3}$ \\
\hline Even Kids & $\mathrm{W}$ & $1(0.5)$ & MFP & 1200 & $\mathrm{CaCO}_{3}$ \\
\hline Aquafresh & $X$ & $1(0.5)$ & $\mathrm{NaF}$ & 1100 & $\mathrm{SiO}_{2}$ \\
\hline Colgate Cavity Protection & $\mathrm{Y}$ & $1(0.5)$ & MFP & 1100 & $\mathrm{CaCO}_{3}$ \\
\hline Colgate Toothpaste & $\mathrm{Z}$ & $1(0.5)$ & $\mathrm{NaF}$ & 1100 & $\mathrm{SiO}_{2}$ \\
\hline Colgate Toothpaste Buble & AA & $1(0.5)$ & $\mathrm{NaF}$ & 1100 & $\mathrm{SiO}_{2}$ \\
\hline Close up Liquifresh & $\mathrm{BB}$ & $1(0.5)$ & $\mathrm{NaF}$ & 1000 & $\mathrm{SiO}_{2}$ \\
\hline Mavatrikids & $\mathrm{CC}$ & $1(0.5)$ & No F & 0.0 & $\mathrm{SiO}_{2}$ \\
\hline Manipulated & $\mathrm{DD}$ & $1(0.5)$ & No $F$ & 0.0 & n.a. \\
\hline
\end{tabular}

*Declared by the manufacturer in the tube label; $\mathrm{MFP}=$ sodium monofluorophosphate; $\mathrm{SiO}_{2}=$ silica; $\mathrm{CaCO}_{3}=$ calcium carbonate; n.a. $=$ not available. 
\pm 12.3 ) and toothpaste K presented the highest amount.

\section{DISCUSSION}

The findings showed that $95.6 \%$ of the children (Table 1) were using toothpastes containing $F$ to brush their teeth, what is crucial in terms of caries control (1) and would explain the relevance of toothpastes for the caries decline observed in Brazil (3). Also, this high percentage found in a city of the southeastern Brazil is in agreement with data from southern region of the country (13).

Moreover, $57.7 \%$ of the F-toothpastes used contained MFP (Table 1), a proportion lower than the $90 \%$ of MFP-based toothpastes consumed by the Brazilian population (personal information). This apparent lower value is explained by the consumption of toothpaste $\mathrm{A}$ by $33.5 \%$ of the children, which contains $\mathrm{NaF}$ as the $\mathrm{F}$ compound.

Moreover, in most toothpastes used, the total fluoride concentration (TF) found was in accordance to the declared in the label (Fig. 1). Also, in most of them the TF concentration was not superior to $1500 \mathrm{ppm} \mathrm{F}$, in agreement to Brazilian regulations (11). However, in order to control caries the toothpaste should contain at least 1000 ppm F (9), which must be chemically soluble in the formulation to have anticaries effect (14).

Thus, the analyses made in this study showed that inalmost $50 \%$ off-toothpastes TSF concentration was lower than that of TF (Fig. 2). This lower value of active fluoride is due the incompatibility between the abrasive agent and the F (15) and, in fact, IF was found bound to the abrasive $\mathrm{CaCO}_{3}$ used in most Brazilian toothpastes (3). IF was found only in toothpastes containing MFP because those with $\mathrm{NaF}$ are in the analyses. formulated with silica as the abrasive agent (Table 1). In MFP molecule, $\mathrm{F}$ is covalently bound to phosphorus but this bond is not stable and the released fluoride ion reacts with the $\mathrm{Ca}^{++}$of the abrasive (8) precipitating as insoluble $\mathrm{CaF}_{2}$, which into the toothpaste is caries inactive (14). This is the main reason why in the toothpastes formulated with $\mathrm{MFP} / \mathrm{CaCO}_{3}$ the manufacturers add $1500 \mathrm{ppm} \mathrm{F}$, which would compensate the amount of $\mathrm{F}$ that is inactivated by the abrasive during product storage. Unfortunately, Brazilian and European regulations do not specify how much of TF should be maintained soluble in a toothpaste formulation.

Nevertheless, in $78 \%$ of the toothpastes used by this sample of Brazilian children the TSF concentration was higher than $1000 \mathrm{ppm} \mathrm{F}$, which is the minimum necessary to have an anticaries effect (9). Among the F-toothpastes presenting less than $1000 \mathrm{ppm}$ (toothpastes

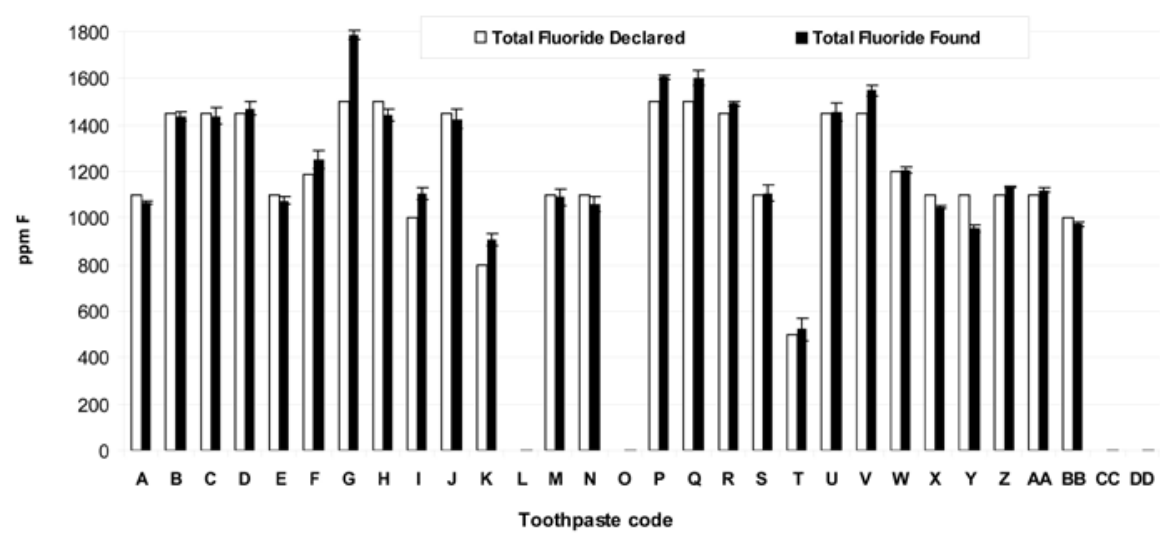

Figure 1. Concentration (ppm F) of total fluoride declared by the manufacturers and found

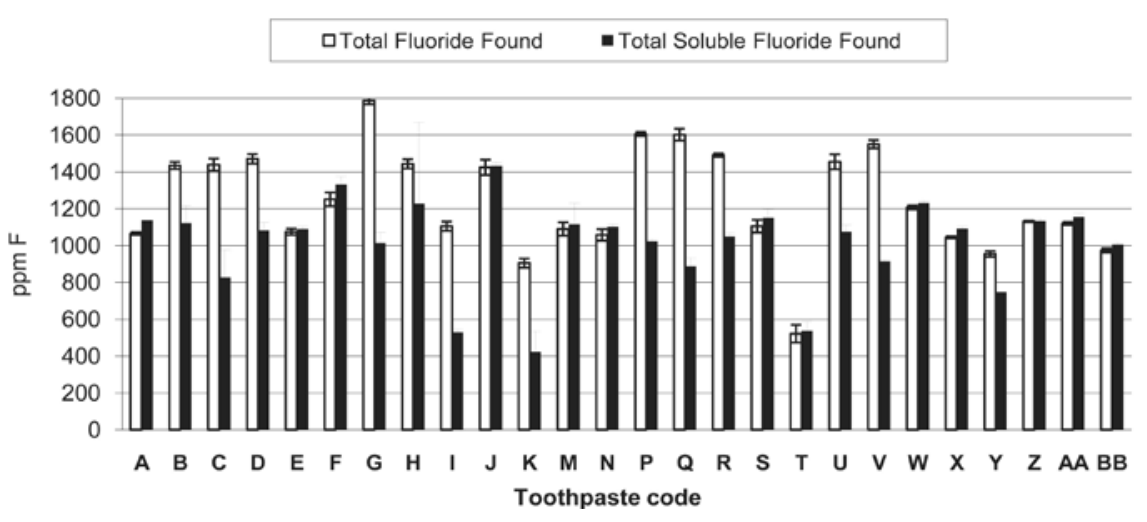

Figure 2. Concentration (ppm F) of total and total soluble fluoride found in the analyses of the fluoridated toothpastes. 
C, I, K, Q, T, V and Y), only one toothpaste (T) is properly formulated (Table 1). This toothpaste is formulated with low $\mathrm{F}$ concentration (500 ppm F) and it presents all $\mathrm{F}$ soluble because it is formulated with $\mathrm{NaF} / \mathrm{SiO}_{2}$. The others are formulated with $\mathrm{MFP} / \mathrm{CaCO}_{3}$, showing that when a toothpaste contains $\mathrm{CaCO} 3$ as an abrasive, the use of MFP as the F form is not a guarantee of stability, reinforcing the need to review the guidelines about the quality of $\mathrm{F}$ in toothpastes marketed.

However, although most toothpastes used by Brazilian children present available fluoride concentration to control caries, F-toothpastes are also considered a factor of fluorosis risk. Thus, the concentration of chemically available $\mathrm{F}$ in toothpastes also determines how much $\mathrm{F}$ is bioavailable in terms of systemic effect $(16,17)$, which should be further considered. Using the present analyses as an example, the risk of fluorosis by the use of toothpaste $\mathrm{A}$, in which its total $1100 \mathrm{ppm} F$ are soluble, could be the same as that provided by the use of toothpaste $\mathrm{B}$, which though formulated with 1450 ppm total $F$, presents only 1122.8 ppm of soluble $\mathrm{F}$.

In conclusion, most toothpastes used by Brazilian children present available fluoride concentration for caries control.

\section{RESUMO}

O requerimento mínimo para que um creme dental tenha potencial anticárie é ele ter fluoreto (F) na concentração de 1000 ppm, o qual porém deve estar solúvel na formulação. Assim, este estudo teve como objetivo conhecer a concentração de F solúvel em dentifrícios usados por 206 crianças brasileiras. Foram determinadas as concentrações de flúor total (FT), o qual representa a soma das concentrações de flúor solúvel (iônico e ionizável) mais o insolúvel (ligado ao abrasivo); de flúor solúvel total (FST), representando o iônico mais o ionizável na forma de monofluorfosfato de sódio (MFP) e de flúor solúvel na forma iônica (FI). A partir destas análises foram calculadas as concentrações de MFP e a \% de F insolúvel (Fins). As análises foram feitas em duplicatas com eletrodo específico. A maioria dos dentifrícios usados (96\%) continham fluoreto e em $84 \%$ desses a concentração de FT encontrada estava de acordo com a declarada na embalagem. Em $78 \%$ dos cremes dentais fluoretados, a concentração de FST encontrada foi igual ou superior a 1000 ppm, variando de 422,3 a 1432,3 ppm F (média \pm DP de 1017,6 $\pm 239,4)$. Os dados mostram que a maioria dos cremes dentais usados pela amostra de crianças brasileiras possui concentração de $\mathrm{F}$ potencialmente ativo para controlar cárie.

\section{ACKNOWLEDGEMENTS}

The authors thank Mr Waldomiro Vieira Filho, from Piracicaba
Dental School, by the technical assistance during the analysis of the toothpastes. This study was supported by State of Minas Gerais Research Foundation, FAPEMIG, (APQ 00464/08). The first author, authorized by the University of Campinas, was a scientific consultant for Colgate Palmolive Company Brazil, during the time that this study was conducted. A preliminary report of this study was presented at the 56th ORCA Congress and the abstract is published in Caries Res 2009;43:204-205.

\section{REFERENCES}

1. Marinho VC, Higgins JP, Sheiham A, Logan S. Fluoride toothpastes for preventing dental caries in children and adolescents. Cochrane Database Syst Rev 2003;(1):CD002278.

2. Bratthall $D$, Hänsel-Petersson G, Sundberg H. Reasons for the caries decline: what do the experts believe? Eur J Oral Sci 1996;104:416422.

3. Cury JA, Tenuta LM, Ribeiro CC, Paes Leme AF. The importance of fluoride dentifrices to the current dental caries prevalence in Brazil. Braz Dent J 2004;15:167-174.

4. ADA. American Dental Association. Council of Scientific Affairs. Acceptance Program Guidelines. Fluoride containing dentifrices; 2005. $26 \mathrm{p}$.

5. Cury JA, Tenuta LM. How to maintain a cariostatic fluoride concentration in the oral environment. Adv Dent Res 2008;20:13-16.

6. Richards A, Banting DW. Fluoride toothpaste. In: Fluoride in Dentistry. Fejerskov O, Ekstrand J, Burt BA. 2nd ed. Copenhagen: Munksgaard; 1996. p 328-343.

7. van Loveren C, Moorer WR, Buijs MJ, van Palenstein Helderman WH. Total and free fluoride in toothpastes from some nonestablished market economy countries. Caries Res 2005;39:224-230.

8. Conde NC, Rebelo MA, Cury JA. Evaluation of the fluoride stability of dentifrices sold in Manaus, AM, Brazil. Pesqui Odontol Bras 2003;17:247-253

9. Walsh T, Worthington HV, Glenny AM, Appelbe P, Marinho VC, Shi $\mathrm{X}$. Fluoride toothpastes of different concentrations for preventing dental caries in children and adolescents. Cochrane Database Syst Rev 2010;(1):CD007868.

10. SCCP. Scientific Committee on Consumer Products. Opinion on the safety of fluorine compounds in oral hygiene products for children under the age of 6 years. Adopted by the SCCP during the 5 th plenary meeting of September 20th, 2005; 2005. SCCP/0882/05.

11. Brazilian Health Ministry. National Sanitary Surveillance Agency (ANVISA). Resolution 79, August 28th, 2000. DO 169. 31/08/2000; 2000. $1415 \mathrm{p}$.

12. Pearce EI. A laboratory evaluation of New Zealand fluoride toothpastes. N Z Dent J 1974;70:98-108.

13. Feldens CA, Rosing CK, dos Santos BZ, Cordeiro MM. Pattern of fluoride-containing dentifrice use and associated factors in preschool children from Ijui, South Brazil. Oral Health Prev Dent 2010;8:277285.

14. Ellwood RP, Fejerskov O, Cury JA, Clarkson, B. Fluoride in caries control. In: Dental caries: the disease and its clinical management. Fejerskov O, Kidd E (Editors). 2nd ed. Oxford: Blackwell \& Munksgaard; 2008. p 287-323.

15. Hattab FN. The state of fluorides in toothpastes. J Dent 1989;17:4754.

16. Ekstrand J, Ehrnebo M. Absorption of fluoride from fluoride dentifrices. Caries Res 1980;14:96-102.

17. Roldi CR, Cury JA. Fluoride metabolism after ingestion of dentifrice. Rev Gaúcha de Odontol 1986;34:425-427. (In Portuguese). 